\title{
The Association Between Air Pollution and Low Birth Weight and Preterm Labor in Ahvaz, Iran
}

This article was published in the following Dove Press journal:

International Journal of Women's Health

\author{
Reihaneh Sarizadeh' \\ Maryam Dastoorpoor ${ }^{2}$ \\ Gholamreza Goudarzi ${ }^{3}$ \\ Masoumeh Simbar' \\ 'Midwifery and Reproductive Health \\ Research Center, School of Nursing and \\ Midwifery, Shahid Beheshti University of \\ Medical Science, Tehran, Iran; \\ ${ }^{2}$ Department of Biostatistics and \\ Epidemiology, Menopause Andropause \\ Research Center, Ahvaz Jundishapur \\ University of Medical Sciences, Ahvaz, Iran; \\ ${ }^{3}$ Department of Environmental Health \\ Engineering, Air Pollution and Respiratory \\ Diseases Research Center, Ahvaz \\ Jundishapur University of Medical Sciences, \\ Ahvaz, Iran
}

Purpose: Pregnant women and fetuses are sensitive to air pollution due to physiological changes in pregnancy. The aim of this study was to determine the relationship between exposure to air pollution, low birth weight and preterm labor in Ahvaz.

Methods: This research was a time-series study. The research sample consisted of all data about low birth weight and preterm labor pregnant women from Imam Khomeini Hospital and Razi Hospital in Ahvaz city. Air pollutant data including $\mathrm{O}_{3}, \mathrm{NO}, \mathrm{NO}_{2}, \mathrm{SO}_{2}, \mathrm{CO}$, $\mathrm{PM}_{10}$ and $\mathrm{PM}_{2.5}$ and climate data were collected from the Environmental Protection Agency and the Khuzestan Province during a 10-year period from 2008 to 2018. The generalized additive models (GAMs) with different air pollutant lags up to 6 days were used.

Results: The results of multiple GAM model have shown that there is a direct and significant relationship between exposure to $\mathrm{PM}_{10}$ at 0-6-day lag, $\mathrm{SO}_{2}$ at 2- and 3-day lag and low birth weight. In addition, there was a direct and significant correlation between exposure to $\mathrm{NO}_{2}, \mathrm{NO}, \mathrm{CO}$ and $\mathrm{PM}_{2.5}$ at 0-6-day lag and preterm labor.

Conclusion: The results indicate the effect of air pollutants on low birth weight and preterm labor. Therefore, pregnant women should be informed about the negative consequences of air pollution and avoid exposure to polluted air during pregnancy.

Keywords: air pollution, low birth weight, preterm labor, Ahvaz, time series

\section{Introduction}

In many countries, the persistence or increase in air pollution is an environmental and public health problem. ${ }^{1}$ Air pollution in 2012 caused 3.7 million deaths in the world, $88 \%$ of which occurs in low- and middle-income countries. ${ }^{2}$ Air pollutants include ozone $\left(\mathrm{O}_{3}\right)$, sulfur dioxide $\left(\mathrm{SO}_{2}\right)$, nitrogen dioxide $\left(\mathrm{NO}_{2}\right)$, carbon monoxide (CO), hydrocarbons, particulate matters (PM), benzene and soot. ${ }^{3}$ Particulate matters are solid particles that are often larger than colloids and can suspend in the air or in combination with another gas temporarily. ${ }^{4}$ These particles can have a significant effect on human health. ${ }^{5}$ Ozone is a very strong oxidizing agent that is an index for photochemical oxidants and is produced by the effect of sunlight on nitrogen dioxide and the generation of radical atomic oxygen. ${ }^{6,7}$ Nitrogen dioxide is a potent corrosive and oxidant gas that physiologically stimulates the lower respiratory tract and is very toxic. ${ }^{8,9}$ At concentrations above the medium and high levels, carbon monoxide is a silent killer, which results in the formation of carboxyhemoglobin in the blood that prevents oxygen intake. ${ }^{4,10}$

Sulfur dioxide is a colorless and non-explosive gas that more than $80 \%$ of it is produced by human beings during the combustion of fossil fuels. ${ }^{11}$ Pregnant women
Correspondence: Masoumeh Simbar Midwifery and Reproductive Health Research Center, Department of Midwifery and Reproductive Health, School of Nursing and Midwifery, Shahid Beheshti University of Medical Science, Tehran, Iran

Email msimbar@gmail.com 
and their fetuses are sensitive to air pollution due to physiological changes that occur during pregnancy. ${ }^{12}$ Exposure to particulate matters less than 2.5 microns is associated with the risk of chronic disorders in pregnancy, including low birth weight, preterm labor and adverse health outcomes of the child (cognitive impairment and asthma). ${ }^{13-17}$ Many pieces of evidence suggest that pregnant women's exposure to air pollution is associated with a number of pregnancy outcomes, including low birth weight, intrauterine growth restriction, preterm labor, fetal death and congenital anomalies. ${ }^{18-21}$ Among the complications due to $\mathrm{SO}_{2}$ and $\mathrm{NO}_{2}$ exposure are increased risk of low birth weight infant during 3rd to 5 th months of gestation, ${ }^{22}$ reduction in the age of pregnancy and complications arising from it such as preterm labor, ${ }^{23,24}$ fetal cardiovascular and pulmonary abnormalities ${ }^{25,26}$ and increased risk of small for gestational age (SGA) newborn. ${ }^{27}$

Preterm labor is one of the side effects of some pollutants. ${ }^{23}$ About 130 million newborns are born annually 15 million of which are due to preterm labor. Prematurity is a major cause of mortality and illnesses that have long-term adverse effects on the health of babies. ${ }^{28}$ Preterm labor is defined as birth before 37 weeks of pregnancy and the newborn is a preterm infant. ${ }^{29}$ According to a meta-analysis conducted in 2015, the prevalence of preterm labor in Iran is reported as $9.2 \% .{ }^{30}$ Evidence suggests that maternal exposure to air pollution during pregnancy is associated with an increased risk of preterm labor, especially in the first trimester of pregnancy. ${ }^{31-34}$

Another side effect of the pollutants is an increased risk of low birth weight. ${ }^{27}$ There are several markers for determining the health status of a community, one of the most important of which is birth weight, which is directly related to infant mortality rates. ${ }^{35}$ Low birth weight refers to the weight below 2500 grams in newborns. ${ }^{36}$ It has been shown in several studies in some Iranian cities, including Guilan and Khuzestan provinces, that the prevalence of low birth weight in Iran was $11.6 \%{ }^{37}$ Another complication of exposure to air pollution is the increased risk of birth of a baby weighing less than 2500 grams. $^{27}$ As several studies have shown, the increase in air pollutants is associated with decreased average birth weight, ${ }^{38,39}$ low birth weight ${ }^{40-45}$ and small for gestational age (SGA) newborns. ${ }^{46,47}$

In 2011, according to the annual average of $\mathrm{PM}_{10}(372$ micrograms per cubic meter), the World Health Organization declared Ahvaz as the most polluted city in Iran and the world ${ }^{48}$ Several studies have been carried out on the effects of air pollutants on health outcomes in Iran. However, it seems that there has not been a time-series study in Ahvaz to examine the acute effects of pollution on hospital admissions due to low birth weight. Therefore, this time-series study is intended to investigate the acute effects of exposure to the daily average of air pollutants, $\mathrm{PM}_{2.5}, \mathrm{CO}, \mathrm{NO}_{2}, \mathrm{PM}_{10}$, $\mathrm{SO}_{2}$ and $\mathrm{O}_{3}$, on the daily number of hospitalized admissions due to low birth weight and preterm labor through the course of 10 years with a 6-day lag of exposure.

\section{Materials and Methods Study Design}

This time-series study was conducted on pregnant women referred to referral Obstetrics and Gynecology Hospitals in Ahvaz city with low birth weight and preterm labor.

\section{The Participants}

The total number of pregnant women referred to the Obstetrics and Gynecology department during the 10year period was 150,766 . The total low birth weights and preterm labor during these 10 years were 863 and 5776 .

\section{Data Collection}

The data included the number of hospital admissions due to low birth weight, preterm labor, air pollutants including $\mathrm{PM}_{2.5}, \mathrm{PM}_{10}, \mathrm{NO}_{2}, \mathrm{NO}, \mathrm{O}_{3}$ and $\mathrm{SO}_{2}$ and meteorological variables including air-temperature and relative humidity recorded since March 2008 to March 2018.

After obtaining permission from the Ethics Committee of Shahid Beheshti University of Medical Sciences, by referring to the referral Obstetrics and Gynecology Hospitals in Ahvaz city, daily information about low birth weight and preterm labor were collected from medical records of pregnant women aged 18 to 35 years during a 10-year period.

Hourly values for air pollutants and meteorological parameters were collected from the Environmental Protection Agency and the Meteorological Office of Khuzestan province, and the daily average amounts were added.

\section{Statistical Analysis}

In this study, descriptive statistics including mean, standard deviation, first, second, third, and minimum and maximum quartets were used. In the analytical section, a multi-pollutant generalized additive model (GAM) was used to estimate the risk ratio (RR) effects of air pollutants on response variables. This is a developed form of GAM 
that has high flexibility. As it can be used for modeling nonlinear trends, this model is used in many studies. ${ }^{49,50}$ Six days are the number of lags for pollutants in the multimodel, and their relationship with the low birth weight and preterm labor was determined.

The optimal number of spline bases was used for each auxiliary variable in the model. The possibility of the presence of some confounding variables including temperature, relative humidity, time trends and days per week was also provided in the model. The effective degree of freedom (EDF) for smoothers was estimated using generalized cross-validation (GCV). All calculations were done with the mgcv package in the $\mathrm{R}$ software, which allows estimating the penalized generalized aggregate models based on regression fined splines by calculating the smoothness. ${ }^{51,52}$

\section{Ethics}

All patients signed a consent form while admitted and allowed their information to be used for research purposes. Meanwhile, researchers received de-identifiable data. Ethics License of the present study was acquired from the Ethics Committee of Shahid Beheshti University of Medical Sciences for Human Research based on the Declaration of Helsinki (Code of ethics: IR.SBMU.PHNM.1396. 906).

\section{Results}

\section{Descriptive Statistic}

The total number of pregnant women referred to the Obstetrics and Gynecology department during the 10year period was 150,766 . The total low birth weights and preterm labor during these 10 years were 863 and 5776 . During the study period, the average daily $\mathrm{PM}_{10}$ and $\mathrm{PM}_{2.5}$ concentrations were 216.9 and $85.7 \mu \mathrm{g} / \mathrm{m}^{3}$, respectively, which were above the WHO-defined limit. The lowest and highest daily temperatures in Ahvaz were 1.4 and $47.8^{\circ} \mathrm{C}$, respectively, with a mean daily average of $27^{\circ} \mathrm{C}$. Other details of the descriptive indexes of consequences, pollutants and meteorological parameters in the city of Ahvaz have been presented in Table 1 in the years of the study.

\section{Relationship Between Exposure to Air Pollutants and Low Birth Weight}

The results of fitting the multiple GAM model on the relationship between air pollutants and low birth weight are shown in Table 2 and Figure 1. This table indicates the information of different fitted models in terms of low birth weight with air pollutants corresponding to 0-6-day lags.

The results of the multiple GAM model show that there is a direct and significant relationship between exposure to $\mathrm{PM}_{10}$ at 0-6-day lags and $\mathrm{SO}_{2}$ at 2- and 3-day lags and low birth weight.

The results showed that there was a significant and direct correlation between exposure to $\mathrm{PM}_{10}$ and low birth weight at zero ( $\mathrm{RR}=1.003$ (95\% CI:1.001-1.004)), one ( $\mathrm{RR}=1.002$ (95\% CI:1.000-1.004)), two (RR=1.003 (95\% CI:1.002$1.005)$ ), three $(\mathrm{RR}=1.004$ (95\% CI:1.002-1.005)), four( $R R=1.002$ (95\% CI:1.001-1.004)), five ( $R R=1.002(95 \%$ CI:1.001-1.004)) and six (RR=1.002 (95\% CI:1.0011.004)) day lags after exposure. In other words, the risk of admission due to low birth weight per $10 \mu \mathrm{g} / \mathrm{m}^{3}$ increase in $\mathrm{PM}_{10}$ at $0-, 1^{-,}, 2-, 3-, 4-, 5-$ and 6-day lags increases by 0.3 ,

Table I Descriptive Indexes of Hospital Admissions Due to Low Birth Weight and Preterm Labor, Air Pollutant Concentrations and Meteorological Parameters in Ahvaz During 2008-2018

\begin{tabular}{|c|c|c|c|c|c|c|c|c|}
\hline Variable (Mean per Day) & $\mathbf{N}$ & Mean & SD & Min & Max & QI & Median & Q3 \\
\hline Low Birth Weight & 863 & 0.2 & 0.6 & 0.0 & 5.0 & 0.0 & 0.0 & 0.0 \\
\hline Premature Birth & 5776 & 1.6 & 1.9 & 0.0 & 12.0 & 0.0 & 1.0 & 2.0 \\
\hline $\mathrm{O}_{3}\left(\mu \mathrm{g} / \mathrm{m}^{3}\right)$ & - & 70.5 & 188.6 & 0.04 & 6520.0 & 26.4 & 42.7 & 64.6 \\
\hline $\mathrm{PM}_{2.5}\left(\mu \mathrm{g} / \mathrm{m}^{3}\right)$ & - & 85.7 & 150.4 & 0.57 & 3938 & 35.9 & 52.7 & 81.2 \\
\hline $\mathrm{PM}_{10}\left(\mu \mathrm{g} / \mathrm{m}^{3}\right)$ & - & 216.9 & 278.3 & 1.8 & 4324.2 & 105.8 & 149.2 & 222.4 \\
\hline $\mathrm{NO}_{2}\left(\mu \mathrm{g} / \mathrm{m}^{3}\right)$ & - & 46.4 & 43.1 & 1.5 & 443.8 & 17.8 & 35.6 & 60.7 \\
\hline $\mathrm{NO}\left(\mu \mathrm{g} / \mathrm{m}^{3}\right)$ & - & 29.1 & 31.0 & 0.12 & 608.7 & 9.1 & 19.6 & 38.2 \\
\hline $\mathrm{CO}\left(\mu \mathrm{g} / \mathrm{m}^{3}\right)$ & - & 1.5 & 2.1 & 0.1 & 70.4 & 0.6 & 1.13 & 2.0 \\
\hline $\mathrm{SO}_{2}\left(\mu \mathrm{g} / \mathrm{m}^{3}\right)$ & - & 48.8 & 57.0 & 0.0 & 907.4 & 19.3 & 35.9 & 59.3 \\
\hline Temperature $\left({ }^{\circ} \mathrm{C}\right)$ & - & 27.0 & 9.4 & 1.4 & 47.8 & 18.4 & 27.7 & 36.0 \\
\hline Relative Humidity (\%) & - & 42.3 & 17.9 & 7.0 & 96.0 & 27.5 & 40.0 & 54.5 \\
\hline
\end{tabular}

Abbreviations: $\mathrm{O}_{3}$, ozone; $\mathrm{SO}_{2}$, sulfur dioxide; $\mathrm{NO}$, nitrogen monoxide; $\mathrm{NO}_{2}$, nitrogen dioxide; $\mathrm{CO}$, carbon monoxide; $\mathrm{PM}$, particulate matter I0 micrometers or less in diameter; $\mathrm{PM}_{2.5}$, particulate matter 2.5 micrometers or less in diameter. 
Table 2 The Results of the Modified GAM of the Relationship Between Air Pollutants and Low Birth Weight of Ahvaz (Increasing the Cases of Daily Low Birth Weight per Increasing 10 Units in a Daily Average of the Pollutant)

\begin{tabular}{|c|c|c|c|c|c|}
\hline Lag & Pollutant & edf & Risk Ratio & $95 \% \mathrm{Cl}$ & P-value* \\
\hline \multirow[t]{7}{*}{ Lag 0} & $\mathrm{O}_{3}$ & 8.578 & 0.988 & $0.978-0.997$ & $0.014^{\dagger}$ \\
\hline & $\mathrm{NO}_{2}$ & 6.073 & 0.872 & $0.848-0.896$ & $<0.001^{\dagger}$ \\
\hline & NO & 5.790 & 0.869 & $0.839-0.900$ & $<0.001^{\dagger}$ \\
\hline & $\mathrm{SO}_{2}$ & 8.399 & 1.010 & $0.999-1.020$ & 0.067 \\
\hline & $\mathrm{CO}$ & 6.152 & 0.616 & $0.369-1.028$ & 0.064 \\
\hline & $\mathrm{PM}_{10}$ & 4.322 & 1.003 & $1.001-1.004$ & $0.002^{\dagger}$ \\
\hline & $\mathrm{PM}_{2.5}$ & 6.559 & 1.000 & $0.996-1.005$ & 0.906 \\
\hline \multirow[t]{7}{*}{ Lag I } & $\mathrm{O}_{3}$ & 8.286 & 0.983 & $0.973-0.994$ & $0.002^{\dagger}$ \\
\hline & $\mathrm{NO}_{2}$ & 5.960 & 0.874 & $0.850-0.898$ & $<0.001^{\dagger}$ \\
\hline & NO & 5.880 & 0.883 & $0.853-0.914$ & $<0.001^{\dagger}$ \\
\hline & $\mathrm{SO}_{2}$ & 6.076 & 1.008 & $0.997-1.018$ & 0.143 \\
\hline & $\mathrm{CO}$ & 4.605 & 0.597 & $0.358-0.996$ & $0.048^{\dagger}$ \\
\hline & $\mathrm{PM}_{10}$ & 3.776 & 1.002 & $1.000-1.004$ & $0.029^{\dagger}$ \\
\hline & $\mathrm{PM}_{2.5}$ & 4.282 & 0.999 & $0.993-1.004$ & 0.640 \\
\hline \multirow[t]{7}{*}{ Lag 2} & $\mathrm{O}_{3}$ & 7.344 & 0.983 & $0.972-0.993$ & $0.002^{\dagger}$ \\
\hline & $\mathrm{NO}_{2}$ & 5.690 & 0.879 & $0.856-0.902$ & $<0.001^{\dagger}$ \\
\hline & NO & 7.683 & 0.897 & $0.868-0.927$ & $<0.001^{\dagger}$ \\
\hline & $\mathrm{SO}_{2}$ & 6.952 & 1.014 & $1.004-1.023$ & $0.005^{\dagger}$ \\
\hline & $\mathrm{CO}$ & 5.568 & 0.884 & $0.602-1.296$ & 0.526 \\
\hline & $\mathrm{PM}_{10}$ & 3.818 & 1.003 & $1.002-1.005$ & $<0.001^{\dagger}$ \\
\hline & $\mathrm{PM}_{2.5}$ & 4.257 & 1.001 & $0.997-1.006$ & 0.589 \\
\hline \multirow[t]{7}{*}{ Lag 3} & $\mathrm{O}_{3}$ & 8.263 & 0.990 & $0.981-0.999$ & $0.027^{\dagger}$ \\
\hline & $\mathrm{NO}_{2}$ & 5.304 & 0.865 & $0.84 I-0.890$ & $<0.001^{\dagger}$ \\
\hline & NO & 8.194 & 0.857 & $0.827-0.889$ & $<0.001^{\dagger}$ \\
\hline & $\mathrm{SO}_{2}$ & 8.341 & 1.012 & $1.002-1.022$ & $0.016^{\dagger}$ \\
\hline & $\mathrm{CO}$ & 5.550 & 0.978 & $0.711-1.346$ & 0.893 \\
\hline & $\mathrm{PM}_{10}$ & 3.657 & 1.004 & $1.002-1.005$ & $<0.001^{\dagger}$ \\
\hline & $\mathrm{PM}_{2.5}$ & 4.021 & 1.002 & $0.997-1.006$ & 0.480 \\
\hline \multirow[t]{7}{*}{ Lag 4} & $\mathrm{O}_{3}$ & 8.192 & 0.992 & $0.984-1.000$ & 0.057 \\
\hline & $\mathrm{NO}_{2}$ & 2.020 & 0.887 & $0.864-0.910$ & $<0.00 \mathrm{I}^{\dagger}$ \\
\hline & NO & 6.926 & 0.894 & $0.865-0.925$ & $<0.001^{\dagger}$ \\
\hline & $\mathrm{SO}_{2}$ & 6.887 & 1.006 & $0.996-1.016$ & 0.212 \\
\hline & $\mathrm{CO}$ & 4.652 & 0.757 & $0.480-1.192$ & 0.229 \\
\hline & $\mathrm{PM}_{10}$ & 4.256 & 1.002 & $1.001-1.004$ & $0.006^{\dagger}$ \\
\hline & $\mathrm{PM}_{2.5}$ & 5.052 & 0.998 & $0.993-1.004$ & 0.588 \\
\hline \multirow[t]{7}{*}{ Lag 5} & $\mathrm{O}_{3}$ & 8.386 & 0.974 & $0.962-0.987$ & $<0.001^{\dagger}$ \\
\hline & $\mathrm{NO}_{2}$ & 7.819 & 0.893 & $0.870-0.916$ & $<0.00 \mathrm{I}^{\dagger}$ \\
\hline & NO & 7.481 & 0.906 & $0.878-0.936$ & $<0.001^{\dagger}$ \\
\hline & $\mathrm{SO}_{2}$ & $4.57 \mid$ & 1.005 & $0.994-1.016$ & 0.376 \\
\hline & $\mathrm{CO}$ & 7.240 & 0.828 & $0.551-1.242$ & 0.360 \\
\hline & $\mathrm{PM}_{10}$ & 4.112 & 1.003 & $1.001-1.005$ & $0.00 \mathrm{I}^{\dagger}$ \\
\hline & $\mathrm{PM}_{2.5}$ & 4.692 & 1.000 & $0.995-1.005$ & 0.917 \\
\hline \multirow[t]{4}{*}{ Lag 6} & $\mathrm{O}_{3}$ & 8.638 & 0.975 & $0.963-0.988$ & $<0.001^{\dagger}$ \\
\hline & $\mathrm{NO}_{2}$ & 6.078 & 0.877 & $0.855-0.900$ & $<0.001^{\dagger}$ \\
\hline & NO & 8.757 & 0.902 & $0.873-0.932$ & $<0.001^{\dagger}$ \\
\hline & $\mathrm{SO}_{2}$ & 4.461 & 1.009 & 0.999-1.019 & 0.088 \\
\hline
\end{tabular}

(Continued)
Table 2 (Continued).

\begin{tabular}{|l|l|l|l|l|l|}
\hline Lag & Pollutant & edf & Risk Ratio & $\mathbf{9 5 \%} \mathbf{C l}$ & P-value* \\
\hline & CO & 6.236 & 0.926 & $0.639-1.343$ & 0.687 \\
& PM $_{10}$ & 4.031 & 1.004 & $1.003-1.006$ & $<0.001^{\dagger}$ \\
& PM $_{2.5}$ & 4.526 & 1.002 & $0.999-1.006$ & 0.222 \\
\hline
\end{tabular}

Notes: ${ }^{\dagger}$ Statistically significant. *Adjusted for trend, seasonality, temperature, relative humidity and weekdays.

$0.2,0.3,0.4,0.2,0.3$ and $0.4 \%$, respectively (Table 2 and Figure 1).

Besides, there was a significant and direct correlation between $\mathrm{SO}_{2}$ and low birth weight at two ( $\mathrm{RR}=1.014(95 \%$ CI:1.004-1.023)) and three ( $R R=1.012$ (95\% CI:1.0021.022)) day lags after exposure. Thus, the risk of admission due to low birth weight per $10 \mu \mathrm{g} / \mathrm{m}^{3}$ increase in $\mathrm{SO}_{2}$ at 2and 3-day lags increases by 1.4 and $1.2 \%$, respectively (Table 2 and Figure 1).

There was a significant and indirect relationship between $\mathrm{NO}$ and $\mathrm{NO}_{2}$ pollutants at $0-6$-day lags and $\mathrm{O}_{3}$ at 2-, 5- and 6-day lags and low birth weight (Table 2 and Figure 1). There was no significant relationship between exposure to $\mathrm{PM}_{2.5}$ and low birth weight at any time in 0-6-day lags (Table 2 and Figure 1).

\section{Relationship Between Exposure to Air Pollutants and Preterm Labor}

The results of fitting the multiple GAM model on the relationship between air pollutants and preterm labor are shown in Table 3 and Figure 2. This table indicates the information of different fitted models preterm labor with air pollutants corresponding to 0-6-day lags.

There was a significant and direct correlation between exposure to $\mathrm{NO}_{2}$ and preterm birth at zero $(\mathrm{RR}=1.031$ (95\% CI:1.025-1.037)), one ( $R R=1.031 \quad$ (95\% CI:1.02 5-1.037)), two (RR $=1.037$ (95\% CI:1.031-1.043)), three $(\mathrm{RR}=1.037$ (95\% CI:1.031-1.043)), four $(\mathrm{RR}=1.039(95 \%$ CI:1.033-1.045)), five ( $R R=1.039$ (95\% CI:1.033-1.045)) and six ( $R R=1.038$ (95\% CI:1.032-1.038)) day lags after exposure. Thus, the risk of admission due to preterm birth per $10 \mu \mathrm{g} / \mathrm{m}^{3}$ increase in $\mathrm{NO}_{2}$ at 0-, 1-, 2-, 3-, 4-, 5- and 6-day lags increases by $3.1,3.1,3.7,3.7,3.9,3.9$ and $3.8 \%$, respectively (Table 3 and Figure 2).

The results also showed that there was a significant and direct correlation between exposure to $\mathrm{NO}$ and preterm birth at zero ( $\mathrm{RR}=1.055$ (95\% CI:1.049-1.061)), one ( $\mathrm{RR}=1.055$ (95\% CI:1.049-1.061)), two (RR=1.056 (95\% CI:1.051- 
O3
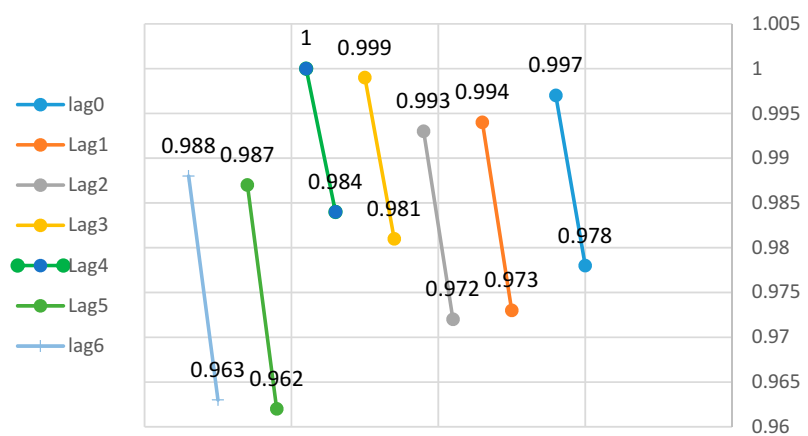

NO

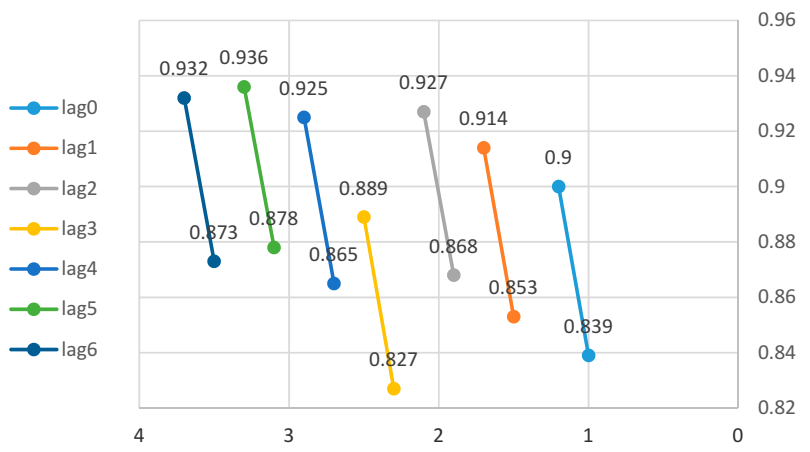

$\mathrm{CO}$
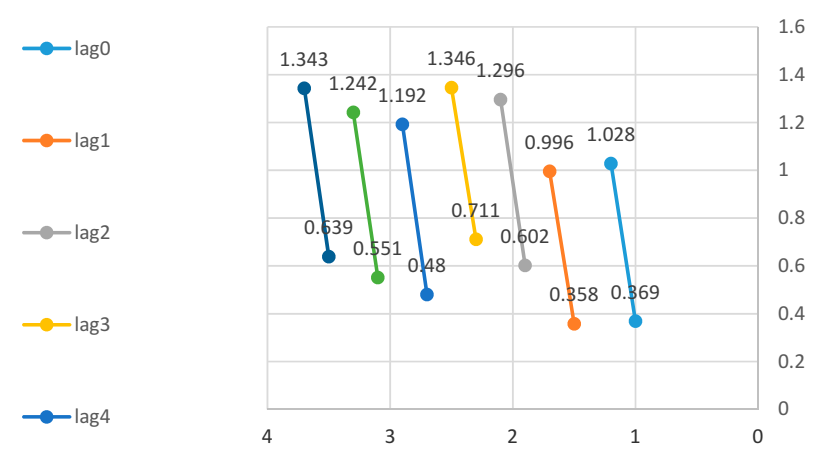

PM2.5

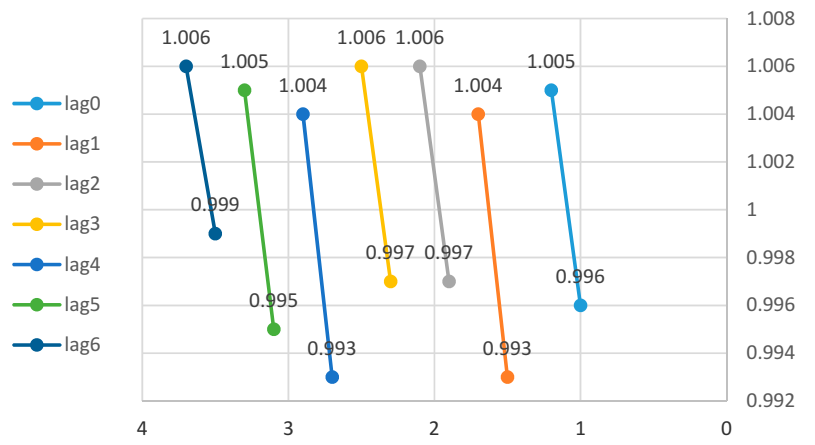

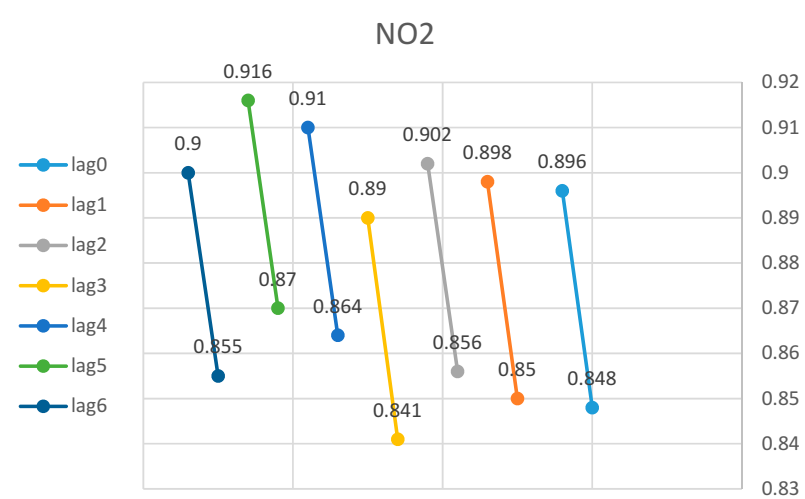

$\mathrm{SO} 2$

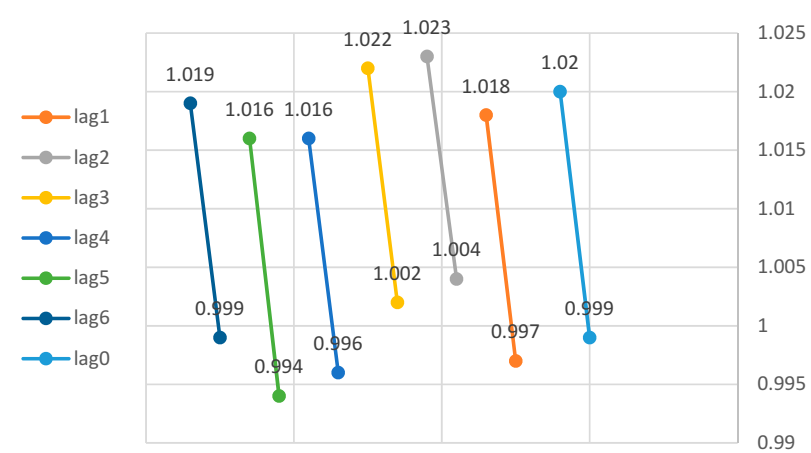

PM10

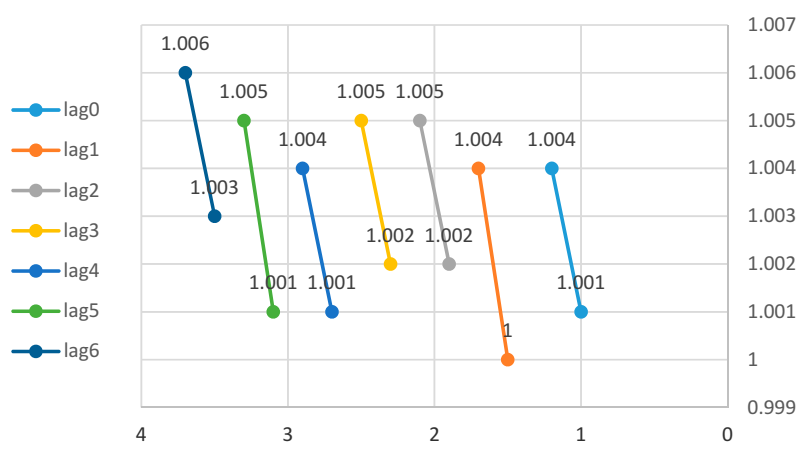

Figure I Risk ratio ( $95 \%$ confidence interval) of low birth weight associated with a 10-unit increase in air pollutant levels for different lags of lag 0-6 days. 
Table 3 The Results of the Modified GAM of the Relationship Between Air Pollutants and Preterm Labor of Ahvaz (Increasing the Cases of Daily Low Birth Weight per Increasing 10 Units in a Daily Average of the Pollutant)

\begin{tabular}{|c|c|c|c|c|c|}
\hline Lag & Pollutant & edf & Risk Ratio & $95 \% \mathrm{Cl}$ & P-value* \\
\hline \multirow[t]{7}{*}{ Lag 0} & $\mathrm{O}_{3}$ & 8.887 & 0.996 & $0.994-0.999$ & $0.004^{\dagger}$ \\
\hline & $\mathrm{NO}_{2}$ & 8.643 & 1.031 & $1.025-1.037$ & $<0.001^{\dagger}$ \\
\hline & NO & 6.196 & 1.055 & $|.049-1.06|$ & $<0.001^{\dagger}$ \\
\hline & $\mathrm{SO}_{2}$ & 4.827 & 0.966 & $0.958-0.973$ & $<0.001^{\dagger}$ \\
\hline & $\mathrm{CO}$ & 8.679 & 1.457 & $|.369-1.55|$ & $<0.001^{\dagger}$ \\
\hline & $\mathrm{PM}_{10}$ & 7.605 & 1.000 & $0.999-1.001$ & 0.971 \\
\hline & $\mathrm{PM}_{2.5}$ & 7.109 & 1.004 & $1.003-1.005$ & $<0.001^{\dagger}$ \\
\hline \multirow[t]{7}{*}{ Lag I } & $\mathrm{O}_{3}$ & 8.790 & 0.996 & $0.993-0.999$ & $0.004^{\dagger}$ \\
\hline & $\mathrm{NO}_{2}$ & 6.338 & 1.031 & $1.025-1.037$ & $<0.001^{\dagger}$ \\
\hline & NO & 8.703 & 1.055 & $|.049-1.06|$ & $<0.001^{\dagger}$ \\
\hline & $\mathrm{SO}_{2}$ & 4.138 & 0.962 & $0.954-0.969$ & $<0.001^{\dagger}$ \\
\hline & $\mathrm{CO}$ & 8.051 & 1.448 & $1.358-1.544$ & $<0.001^{\dagger}$ \\
\hline & $\mathrm{PM}_{10}$ & 8.716 & 1.000 & 0.999-1.001 & 0.381 \\
\hline & $\mathrm{PM}_{2.5}$ & 8.477 & 1.004 & $1.003-1.005$ & $<0.001^{\dagger}$ \\
\hline \multirow[t]{7}{*}{ Lag 2} & $\mathrm{O}_{3}$ & 8.880 & 0.994 & $0.991-0.997$ & $<0.001^{\dagger}$ \\
\hline & $\mathrm{NO}_{2}$ & 8.592 & 1.037 & $1.031-1.043$ & $<0.001^{\dagger}$ \\
\hline & No & 7.224 & 1.056 & $1.051-1.062$ & $<0.001^{\dagger}$ \\
\hline & $\mathrm{SO}_{2}$ & 8.259 & 0.962 & $0.955-0.970$ & $<0.001^{\dagger}$ \\
\hline & $\mathrm{CO}$ & 8.799 & 1.451 & $1.365-1.542$ & $<0.001^{\dagger}$ \\
\hline & $\mathrm{PM}_{10}$ & 7.124 & 0.999 & $0.997-1.000$ & $0.006^{\dagger}$ \\
\hline & $\mathrm{PM}_{2.5}$ & 8.375 & 1.004 & $1.003-1.005$ & $<0.001^{\dagger}$ \\
\hline \multirow[t]{7}{*}{ Lag 3} & $\mathrm{O}_{3}$ & 8.873 & 0.997 & $0.995-1.000$ & $0.022^{\dagger}$ \\
\hline & $\mathrm{NO}_{2}$ & 7.969 & 1.037 & $1.031-1.043$ & $<0.00 \mathrm{I}^{\dagger}$ \\
\hline & NO & 6.001 & 1.057 & $1.051-1.062$ & $<0.001^{\dagger}$ \\
\hline & $\mathrm{SO}_{2}$ & 5.211 & 0.959 & $0.952-0.967$ & $<0.001^{\dagger}$ \\
\hline & $\mathrm{CO}$ & 8.491 & 1.471 & $1.387-1.560$ & $<0.001^{\dagger}$ \\
\hline & $\mathrm{PM}_{10}$ & 7.394 & 0.999 & $0.998-1.000$ & $0.022^{\dagger}$ \\
\hline & $\mathrm{PM}_{2.5}$ & 8.739 & 1.004 & $1.003-1.005$ & $<0.001^{\dagger}$ \\
\hline \multirow[t]{7}{*}{ Lag4 } & $\mathrm{O}_{3}$ & 8.803 & 0.997 & $0.995-1.000$ & $0.021^{\dagger}$ \\
\hline & $\mathrm{NO}_{2}$ & 7.333 & 1.039 & $1.033-1.045$ & $<0.001^{\dagger}$ \\
\hline & NO & 8.738 & 1.057 & $1.051-1.062$ & $<0.001^{\dagger}$ \\
\hline & $\mathrm{SO}_{2}$ & 4.224 & 0.963 & 0.956-0.97। & $<0.00 \mathrm{I}^{\dagger}$ \\
\hline & $\mathrm{CO}$ & 8.357 & 1.472 & $1.388-1.562$ & $<0.001^{\dagger}$ \\
\hline & $\mathrm{PM}_{10}$ & 8.059 & 0.998 & $0.997-0.999$ & $<0.00 \mathrm{I}^{\dagger}$ \\
\hline & $\mathrm{PM}_{2.5}$ & 8.862 & 1.003 & $1.002-1.005$ & $<0.00 \mathrm{I}^{\dagger}$ \\
\hline \multirow[t]{7}{*}{ Lag 5} & $\mathrm{O}_{3}$ & 8.766 & 0.995 & $0.992-0.998$ & $<0.001^{\dagger}$ \\
\hline & $\mathrm{NO}_{2}$ & 7.987 & 1.039 & $1.033-1.045$ & $<0.00 \mathrm{I}^{\dagger}$ \\
\hline & NO & 8.562 & 1.057 & $1.052-1.063$ & $<0.00 \mathrm{I}^{\dagger}$ \\
\hline & $\mathrm{SO}_{2}$ & 4.968 & 0.959 & $0.952-0.967$ & $<0.001^{\dagger}$ \\
\hline & $\mathrm{CO}$ & 8.366 & 1.455 & $1.369-1.546$ & $<0.00 \mathrm{I}^{\dagger}$ \\
\hline & $\mathrm{PM}_{10}$ & 6.915 & 0.997 & $0.996-0.998$ & $<0.001^{\dagger}$ \\
\hline & $\mathrm{PM}_{2.5}$ & 6.536 & 1.003 & $1.001-1.004$ & $<0.00 \mathrm{I}^{\dagger}$ \\
\hline \multirow[t]{4}{*}{ Lag 6} & $\mathrm{O}_{3}$ & 8.856 & 0.995 & $0.992-0.998$ & $<0.001^{\dagger}$ \\
\hline & $\mathrm{NO}_{2}$ & 6.366 & 1.038 & $1.032-1.044$ & $<0.001^{\dagger}$ \\
\hline & NO & 7.450 & 1.057 & $1.051-1.062$ & $<0.001^{\dagger}$ \\
\hline & $\mathrm{SO}_{2}$ & 3.975 & 0.959 & $0.95 I-0.966$ & $<0.001^{\dagger}$ \\
\hline
\end{tabular}

(Continued)
Table 3 (Continued).

\begin{tabular}{|l|l|l|l|l|l|}
\hline Lag & Pollutant & edf & Risk Ratio & $\mathbf{9 5 \%}$ Cl & P-value* \\
\hline & CO & 8.304 & 1.492 & $1.404-1.585$ & $<0.00 I^{\dagger}$ \\
& PM $_{10}$ & 8.193 & 0.998 & $0.997-0.999$ & $<0.00 I^{\dagger}$ \\
& PM $_{2.5}$ & 8.744 & 1.004 & $1.002-1.005$ & $<0.00 I^{\dagger}$ \\
\hline
\end{tabular}

Notes: ${ }^{\dagger}$ Statistically significant. *Adjusted for trend, seasonality, temperature, relative humidity and weekdays.

1.062)), three ( $R R=1.057$ (95\% CI:1.051-1.062)), four $(\mathrm{RR}=1.039$ (95\% CI:1.033-1.045)), five $(\mathrm{RR}=1.057$ (95\% CI:1.051-1.062)) and six (RR=1.057 (95\% CI:1.0521.063)) day lags after exposure. Thus, the risk of admission due to preterm birth per $10 \mu \mathrm{g} / \mathrm{m}^{3}$ increase in NO at $0-, 1-, 2-$, 3-, 4-, 5- and 6-day lags increases by 5.5, 5.5, 5.6, 5.7, 5.7, 5.7 and $5.7 \%$, respectively (Table 3 and Figure 2 ).

The results also showed that there was a significant and direct correlation between exposure to $\mathrm{CO}$ and preterm birth at zero ( $\mathrm{RR}=1.457$ (95\% CI:1.369-1.551)), one $(\mathrm{RR}=1.448$ (95\% CI:1.358-1.544)), two $(\mathrm{RR}=1.451(95 \%$ CI:1.365-1.542)), three (RR=1.471 (95\% CI:1.3871.560)), four ( $R R=1.472$ (95\% CI:1.388-1.562)), five $(\mathrm{RR}=1.455(95 \% \mathrm{CI}: 1.369-1.546))$ and six $(\mathrm{RR}=1.492$ (95\% CI:1.404-1.585)) day lags after exposure (Table 3 and Figure 2).

Finally, there was a significant and direct correlation between exposure to $\mathrm{PM}_{2.5}$ and preterm birth at zero $(\mathrm{RR}=1.004$ (95\% CI:1.003-1.005)), one ( $\mathrm{RR}=1.004$ (95\% CI:1.003-1.005)), two (RR=1.004 (95\% CI:1.003-1.005)), three $(\mathrm{RR}=1.004(95 \% \mathrm{CI}: 1.003-1.005))$, four $(\mathrm{RR}=1.003$ (95\% CI:1.002-1.005)), five ( $R R=1.003$ (95\% CI:1.0011.004)) and six ( $R R=1.004$ (95\% CI:1.002-1.005)) day lags after exposure. Thus, the risk of admission due to preterm delivery per $10 \mu \mathrm{g} / \mathrm{m}^{3}$ increase in $\mathrm{PM}_{2.5}$ at $0-, 1-$, 2-, 3- and 6-day lags increases by $0.4 \%$ and that of the 4and 5-day lags increases by $3 \%$ (Table 3 and Figure 2).

A significant and inverse relationship was found between exposure to $\mathrm{O}_{3}, \mathrm{SO}_{2}$ and $\mathrm{PM}_{10}$ and preterm birth (Table 3 and Figure 2).

\section{Discussion}

Air pollution has been investigated in many studies as a factor damaging fetal development. ${ }^{20,53,54}$ The purpose of this study was to investigate the short-term effects of air pollution on hospital admissions due to low birth weight and preterm labor in Ahvaz. Rapid cell growth and limitation of limb metabolism, especially embryonic growth systems, are susceptible to exposure to air pollutants. ${ }^{20}$ 
$\mathrm{O3}$

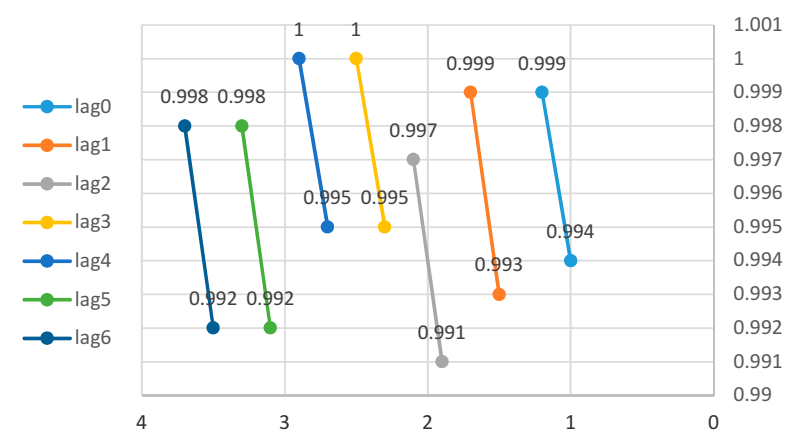

NO

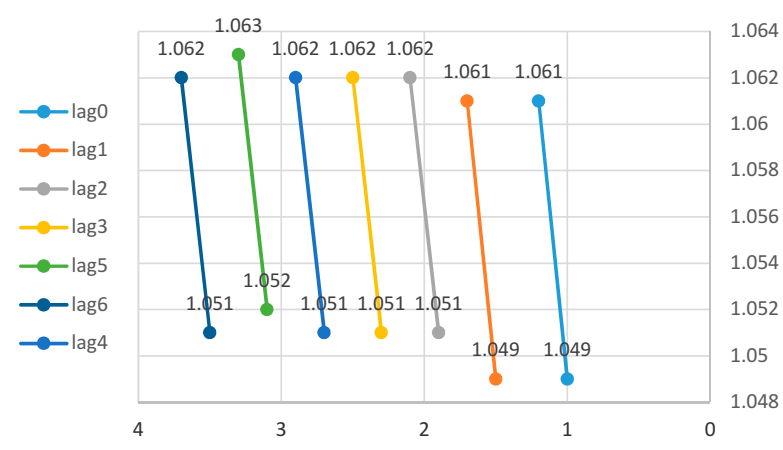

PM2.5

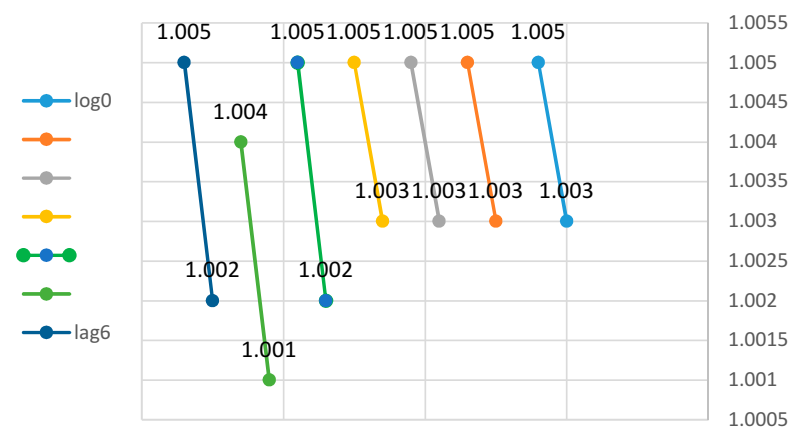

CO



$\mathrm{SO} 2$

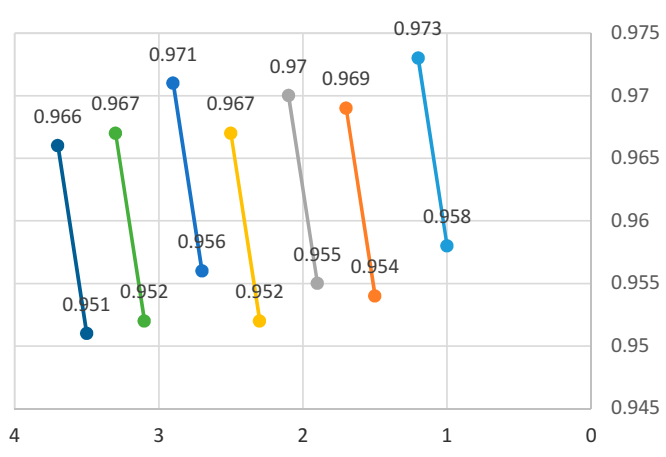

NO2

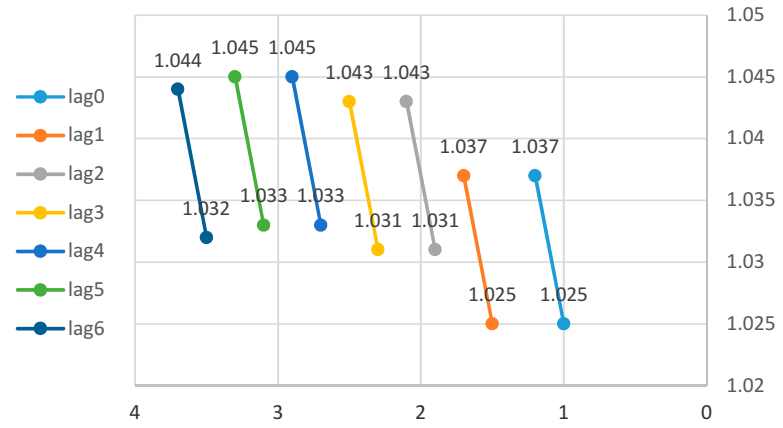

PM10

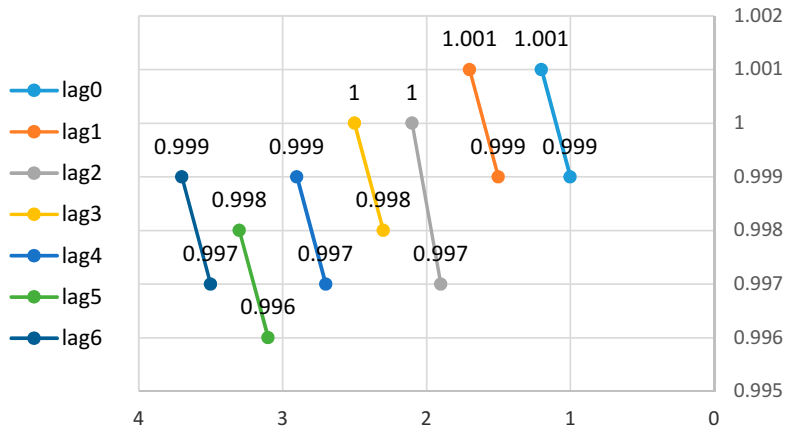

Figure 2 Risk ratio (95\% confidence interval) of preterm labor associated with a 10-unit increase in air pollutant levels for different lags of lag $0-6$ days. 
The production of free radicals caused by pollution could create an inflammatory response that increases blood concentration and decreased placental perfusion caused by changes in blood viscosity may be associated with undesirable outcomes of pregnancy including low birth weight and preterm labor. ${ }^{55}$

\section{Low Birth Weight}

The results showed that there is a direct and significant relationship between exposure to $\mathrm{PM}_{10}$ and low birth weight. In this regard, numerous studies have confirmed the relationship between exposure to $\mathrm{PM}_{10}$ and low birth weight. ${ }^{56,57}$ The results of a study in Mongolia showed that the exposure to $\mathrm{PM}_{10}$ was associated with a 12.2 $\mathrm{g}$ weight reduction in the newborn. ${ }^{58}$ However, in Salam et al, no correlation was observed between the increase in $\mathrm{PM}_{10}$ and low birth weight; ${ }^{59}$ however, exposure to $\mathrm{PM}_{10}$ may cause its passage through the blood, increased blood viscosity and activated systemic oxidative stress followed by impaired fetal growth. ${ }^{60}$

Results also showed that there is a significant and direct relationship between exposure to $\mathrm{SO}_{2}$ and low birth weight. In other studies, an increased risk ratio of low birth weight has been confirmed by increasing $\mathrm{SO}_{2}$. In a longitudinal study in Sao Paulo and a systematic study by Jacob et al, exposure to $\mathrm{SO}_{2}$ was associated with an increased risk ratio of low birth weight. ${ }^{61,62}$ In a casecontrol study in China, the increased maternal exposure to $\mathrm{SO}_{2}$ in the first month of pregnancy was associated with an increased risk ratio of low birth weight. ${ }^{63}$ However, a study in China with a time-series approach showed that pregnant women's weekly exposure to $\mathrm{SO}_{2}$ has no significant relationship with low birth weight. ${ }^{64}$ However, according to the results of the present and several other studies that confirmed the finding, it seems that exposure to $\mathrm{SO}_{2}$ pollutant can change blood viscosity due to an increase in coagulation factors. ${ }^{65}$ Following the change in viscosity, the blood supply to the placenta, placental function $^{66}$ and placental oxygenation ${ }^{39}$ are reduced, which can lead to low birth weight.

The results of the present study showed that the exposure of pregnant women to $\mathrm{NO}_{2}$ reduces the risk ratio of low birth weight. In a Chinese time-series study, the exposure of pregnant women to $\mathrm{NO}_{2}$ was not significantly related to low birth weight. ${ }^{64}$ Salam et al did not observe any correlation between $\mathrm{NO}_{2}$ and low birth weight as well. ${ }^{59}$ Although the results of the studies show that exposure to $\mathrm{NO}_{2}$ pollutants is associated with an increased risk ratio of low birth weight, ${ }^{40,67-69}$ given the controversial findings on the effect of $\mathrm{NO}_{2}$, further research is needed in this regard.

The results of this study showed that the exposure of pregnant women to $\mathrm{O}_{3}$ reduces the risk of low birth weight. However, in other studies, it has been shown that exposure to $\mathrm{O}_{3}$ has been associated with a reduction in birth weight. ${ }^{43,58,59}$

Some studies have examined the effects of $\mathrm{PM}_{2.5}$ on preterm labor and low birth weight in sensitive exposure window. ${ }^{70-72}$ Moreover, the results of this study showed that there is no significant relationship between exposure to $\mathrm{PM}_{2.5}$ and low birth weight. Recent studies have shown that exposure to $\mathrm{PM}_{2.5}$ is associated with a reduction in birth weight. ${ }^{24,41,73}$ However, in another paper for each $10 \mu \mathrm{g} / \mathrm{m}^{3}$ increase in $\mathrm{PM}_{10}$ and $\mathrm{PM}_{2.5}$, low birth weight was reduced by 0.12 and $0.44 \%$ at 6 - and 3-day lags, respectively. ${ }^{45}$ In this study, only exposure to $\mathrm{PM}_{10}$ showed a meaningful relationship with low birth weight. The inconsistency in the findings emphasizes the need for further research on low birth weight mechanism.

Regarding the observed reverse effects, it seems that the harvesting effect is involved in this issue. This effect means that if the increase in air pollutants in the first days of exposure leads to low birth weight, after prolonged exposure to air pollutants, decreased daily low birth weight is expected. In other words, the relationship between air pollution and low birth weight during an increase in the volatility of air pollutants is concentrated in only a few days. ${ }^{74}$

\section{Preterm Labor}

The results of the analysis show that exposure to nitric oxides, including $\mathrm{NO}$ and $\mathrm{NO}_{2}$, is associated with an increased risk of preterm labor. In this regard, the results of Dastoorpoor et al showed that for each $10 \mu \mathrm{g} / \mathrm{m}^{3}$ increase in $\mathrm{NO}_{2}$, the risk of preterm labor increases. ${ }^{48}$ Additionally, the results of a systematic review and metaanalysis showed that increased $\mathrm{NO}_{2}$ was associated with an increased risk of preterm labor. ${ }^{75}$ Other studies confirm this finding. ${ }^{40,76,77}$ However, some studies do not confirm this finding. ${ }^{75,78-80}$

In fact, exposure to $\mathrm{NO}_{2}$ during pregnancy increases lipid peroxidation in the placenta and increases the incidence of postpartum fetal mortality and postpartum growth disorders. ${ }^{81}$ In addition, $\mathrm{NO}_{2}$ is capable of oxidizing tissue components (eg, protein, fat) and suppressing antioxidant protective systems. $^{82}$ 
The results of the present study showed that there is a significant and direct correlation between exposure to $\mathrm{CO}$ and preterm labor. Accordingly, the results of the study in California showed that exposure to $\mathrm{CO}$ in the first and third trimesters of pregnancy was followed by 27 and $36 \%$ of preterm labor, respectively. ${ }^{83}$ Other studies also found that increased $\mathrm{CO}$ is associated with an increased risk ratio of preterm labor. ${ }^{48,80,84}$ The adverse effects of exposure to $\mathrm{CO}$ on human health are due to the possible mechanism of $\mathrm{CO}$ for endothelial inflammation and immune system activation. ${ }^{1}$

The results of the present study showed that there is a significant and direct relationship between exposure to $\mathrm{PM}_{2.5}$ and preterm labor. In this regard, Guan et al showed that for $10 \mu \mathrm{g} / \mathrm{m}^{3}$ increase in $\mathrm{PM}_{2.5}$ in the short- and long-term exposures, the risk of preterm labor increases by 0.52 and $3.13 \%$, respectively. ${ }^{85}$ The results of Liang et al showed that $1 \%, 6 \%$, and $7 \%$ increases in risk of preterm labor and $20 \%, 18 \%$, and $20 \%$ increases in risk of LBW, with each $10 \mu \mathrm{g} / \mathrm{m}^{3}$ increase in PM2.5 from trimester 1 to trimester 3, respectively. ${ }^{71}$ Other studies have shown that maternal exposure to high $\mathrm{PM}_{2.5}$ levels in the first trimester of pregnancy ${ }^{86,87}$ and length of pregnancy ${ }^{40}$ are associated with preterm labor. However, there was no relationship between PM2.5 and preterm labor in the study of Sun et al. ${ }^{88}$ However, the results of Rappazzo et $\mathrm{al}^{89}$ and the systematic review and meta-analysis by $\mathrm{Li}$ et $\mathrm{al}^{90}$ confirm this finding. It seems that exposure of pregnant mothers to $\mathrm{PM}_{2.5}$ during pregnancy has adverse effects on the growth, development and performance of the placenta. ${ }^{91,92}$

The results of the present study showed that there is a significant and inverse relationship between exposure to $\mathrm{PM}_{10}$ and preterm labor. In a time-series study in Rome, it was confirmed that exposure to $\mathrm{PM}_{10}$ was not significantly associated with the outcome of preterm labor. ${ }^{93}$ However, in other studies, exposure to $\mathrm{PM}_{10}$ was associated with a direct and significant risk of preterm labor. ${ }^{48,63,69,94}$ The findings seem contradictory in this regard, and studies with more precise methods are required.

The results of this study showed a significant and inverse relationship between the exposure of pregnant women to $\mathrm{O}_{3}$ and preterm labor. Findings of the relationship between exposure to $\mathrm{O}_{3}$ and the increased risk of preterm labor are highly controversial. While many studies show a positive and significant relationship, some studies did not achieve such a result. In a study in 24
Canadian cities, exposure to $\mathrm{O}_{3}$ at zero-, 1- and 6-day lag was associated with an increased risk of preterm labor. ${ }^{75}$ Other studies also reported a significant relationship between $\mathrm{O}_{3}$ exposure and preterm labor. ${ }^{95,96}$ However, there was no significant relationship between $\mathrm{O}_{3}$ exposure and preterm labor in a time-series study by Darrow et al in Atlanta and Schifano et al in Rome, Italy. ${ }^{32,93}$ In the present study, there was a significant and inverse relationship between exposure to $\mathrm{SO}_{2}$ and the risk of preterm labor. However, in other studies, daily exposure to $\mathrm{SO}_{2}$ was associated with an increase in preterm labor. ${ }^{40,45,77}$ These contradictory findings show the need for more and more detailed studies.

Exposure to particulate air pollution during pregnancy can lead to acute inflammation in the lungs and other organs, including the placenta, which is associated with an increase in preterm labor. ${ }^{97}$ Placenta has a unique role in transferring gas, nutrients and waste materials between mother and fetus. ${ }^{98}$ High levels of exposure to particulate matter may increase the number of cells with immature chromatin. ${ }^{99,100}$ It can also be effective in reducing the birth weight of the baby with potentially harmful effects on DNA. ${ }^{101}$ The production of free radicals from air pollution can lead to inflammatory responses that can be associated with adverse pregnancy outcomes, including low birth weight and preterm labor, by increasing blood levels and decreasing placental perfusion due to changes in viscosity of the blood. ${ }^{55}$ In addition, increased systemic inflammation may also contribute to the restriction of intrauterine growth due to interference in the transfer of nutrients to the fetus and the reduction of oxygen supply to the fetus. ${ }^{101}$

One of the strengths of this study is that for the first time, the relationship between pollutants and low birth weight was carried out during a ten-year period in Ahvaz. It is suggested to perform similar studies in other metropolitan areas where access to pollutant data and a larger population of people with pregnancy outcomes is provided to provide precise information on planning for prevention. Also, cohort studies aimed to investigate the relationship between pregnant women exposure in different trimesters of pregnancy and the consequences of preterm labor and low birth weight in other metropolises.

The incomplete recording of air pollutants by the sensors and the inherent limitation of the ecological study that make the results of this study hard to transmit to individual levels directly are among the limitations of this research. 


\section{Conclusion}

The results of this study showed that there is a direct relationship between the exposure of pregnant women to $\mathrm{PM}_{10}$, $\mathrm{SO}_{2}$ and low birth weight as well as exposure to $\mathrm{NO}, \mathrm{PM}_{2.5}$, $\mathrm{NO}_{2}, \mathrm{CO}$ and preterm labor. This evidence emphasizes the need to implement policies for reducing air pollution to decrease the risk of preterm labor and low birth weight.

\section{Acknowledgments}

This article was part of the thesis by the Research Council of Shahid Beheshti University. Hereby the collaborations of officials and staff of the hospitals in performing sampling and cooperation of the air quality control company and the Ahvaz Environmental Protection Agency are appreciated.

\section{Disclosure}

The authors report no conflicts of interest in this work.

\section{References}

1. WHO. Ambient Air Pollution: A Global Assessment of Exposure and Burden of Disease. World Health Organization; 2016.

2. World Health Organization. Global Nutrition Targets 2025: Stunting Policy Brief. World Health Organization; 2014.

3. Kagawa J. Health effects of air pollutants and their management. Atmos Environ. 1984;18(3):613-620. doi:10.1016/0004-6981(84) 90181-1

4. Wark K, Warner CF. Air Pollution: Its Origin and Control. New York, NY: Harper and Row Publishers; 1981:526. None; Medium: X; Size.

5. World Health Organization. Air Quality Guidelines for Europe; 2000.

6. Cheremisinoff NP. Handbook of Air Pollution Prevention and Control. Elsevier; 2002.

7. Sanhueza PA, Reed GD, Davis WT, Miller TL. An environmental decision-making tool for evaluating ground-level ozone-related health effects. $J$ Air Waste Manag Assoc. 2003;53 (12):1448-1459. doi:10.1080/10473289.2003.10466324

8. Godish T. Indoor Environmental Quality. CRC press; 2016.

9. Sproull WT, editor. Air Pollution and Its Control. ERIC; 1972.

10. Raub J, McMullen T. Air Quality Criteria for Carbon Monoxide. Washington, DC: United States Environmental Protection Agency; 1991.

11. Spedding DJ. Air Pollution. London: Oxford University Press; 1974.

12. Suh YJ, Kim H, Seo JH, et al. Different effects of PM10 exposure on preterm birth by gestational period estimated from time-dependent survival analyses. Int Arch Occup Environ Health. 2009;82(5):613-621. doi:10.1007/s00420-008-0380-7

13. Basagaña $X$, Esnaola M, Rivas $I$, et al. Neurodevelopmental deceleration by urban fine particles from different emission sources: a longitudinal observational study. Environ Health Perspect. 2016;124(10):1630-1636. doi:10.1289/EHP209

14. Brunst KJ, Ryan PH, Brokamp C, et al. Timing and duration of traffic-related air pollution exposure and the risk for childhood wheeze and asthma. Am J Respir Crit Care Med. 2015;192 (4):421-427. doi:10.1164/rccm.201407-1314OC
15. Lamichhane DK, Leem J-H, Lee J-Y, Kim H-C. A meta-analysis of exposure to particulate matter and adverse birth outcomes. Environ Health Toxicol. 2015;30:e2015011. doi:10.5620/eht.e2015011

16. Malmqvist E, Rignell-Hydbom A, Tinnerberg H, et al. Maternal exposure to air pollution and birth outcomes. Environ Health Perspect. 2011;119(4):553-558. doi:10.1289/ehp.1002564

17. Schwartz J, Spix C, Touloumi G, et al. Methodological issues in studies of air pollution and daily counts of deaths or hospital admissions. J Epidemiol Community Health. 1996;50 Suppl 1: S3-S11. doi:10.1136/jech.50.Supp1_1.S3

18. Glinianaia SV, Rankin J, Bell R, Pless-Mulloli T, Howel D. Particulate air pollution and fetal health: a systematic review of the epidemiologic evidence. Epidemiology. 2004;15(1):36-45. doi:10.1097/01.ede.0000101023.41844.ac

19. Sapkota A, Chelikowsky AP, Nachman KE, Cohen AJ, Ritz B. Exposure to particulate matter and adverse birth outcomes: a comprehensive review and meta-analysis. Air Qual Atmos Health. 2012;5(4):369-381. doi:10.1007/s11869-010-0106-3

20. Sram RJ, Binkova B, Dejmek J, Bobak M. Ambient air pollution and pregnancy outcomes: a review of the literature. Environ Health Perspect. 2005;113(4):375-382. doi:10.1289/ehp.6362

21. Vrijheid M, Martinez D, Manzanares S, et al. Ambient air pollution and risk of congenital anomalies: a systematic review and meta-analysis. Environ Health Perspect. 2011;119(5):598-606. doi:10.1289/ehp.1002946

22. Lee BE, Ha EH, Park HS, et al. Exposure to air pollution during different gestational phases contributes to risks of low birth weight. Hum Reprod. 2003;18(3):638-643. doi:10.1093/humrep/ $\operatorname{deg} 102$

23. Llop S, Ballester F, Estarlich M, Esplugues A, Rebagliato M, Iniguez C. Preterm birth and exposure to air pollutants during pregnancy. Environ Res. 2010;110(8):778-785.

24. Mohorovic L. The level of maternal methemoglobin during pregnancy in an air-polluted environment. Environ Health Perspect. 2003;111(16):1902-1905. doi:10.1289/ehp.6055

25. Dadvand P, Rankin J, Rushton S, Pless-Mulloli T. Ambient air pollution and congenital heart disease: a register-based study. Environ Res. 2011;111(3):435-441. doi:10.1016/j.envres.2011.01.022

26. Rankin J, Chadwick T, Natarajan M, Howel D, Pearce MS, PlessMulloli T. Maternal exposure to ambient air pollutants and risk of congenital anomalies. Environ Res. 2009;109(2):181-187. doi:10.1016/j.envres.2008.11.007

27. Hansen C, Neller A, Williams G, Simpson R. Low levels of ambient air pollution during pregnancy and fetal growth among term neonates in Brisbane, Australia. Environ Res. 2007;103 (3):383-389. doi:10.1016/j.envres.2006.06.010

28. Goldenberg RL, Culhane JF, Iams JD, Romero R. Epidemiology and causes of preterm birth. Lancet. 2008;371(9606):75-84. doi:10.1016/S0140-6736(08)60074-4

29. Cunningham FG, Leveno KJ, Bloom SL, et al. Obstetricia de Williams. Brasil: McGraw Hill; 2016.

30. Vakilian K, Ranjbaran M, Khorsandi M, Sharafkhani N, Khodadost M. Prevalence of preterm labor in Iran: a systematic review and meta-analysis. Int J Reprod Biomed (Yazd). 2015;13 (12):743-748. doi:10.29252/ijrm.13.12.743

31. Chang HH, Warren JL, Darrow LA, Reich BJ, Waller LA. Assessment of critical exposure and outcome windows in time-toevent analysis with application to air pollution and preterm birth study. Biostatistics. 2015;16(3):509-521. doi:10.1093/biostatistics/kxu060

32. Darrow LA, Klein M, Flanders WD, et al. Ambient air pollution and preterm birth: a time-series analysis. Epidemiology (Cambridge, Mass). 2009;20(5):689. doi:10.1097/EDE.0b013e3181a7128f

33. Laurent $\mathrm{O}, \mathrm{Hu} \mathrm{J}, \mathrm{Li} \mathrm{L}$, et al. A statewide nested case-control study of preterm birth and air pollution by source and composition: California, 2001-2008. Environ Health Perspect. 2016;124 (9):1479-1486. doi:10.1289/ehp.1510133 
34. Olsson D, Mogren I, Forsberg B. Air pollution exposure in early pregnancy and adverse pregnancy outcomes: a register-based cohort study. BMJ Open. 2013;3:2. doi:10.1136/bmjopen-2012001955

35. Blumenshine P, Egerter S, Barclay CJ, Cubbin C, Braveman PA. Socioeconomic disparities in adverse birth outcomes: a systematic review. Am J Prev Med. 2010;39(3):263-272. doi:10.1016/j. amepre.2010.05.012

36. Kramer MS. Determinants of low birth weight: methodological assessment and meta-analysis. Bull World Health Organ. 1987;65 (5):663.

37. Safavi S, Muhammadi I, editors. Prevalence of anemia during pregnancy in 2001. Ninth Congr Nutr. 2003.

38. Dugandzic R, Dodds L, Stieb D, Smith-Doiron M. The association between low level exposures to ambient air pollution and term low birth weight: a retrospective cohort study. Environ Health. 2006;5(1):3. doi:10.1186/1476-069X-5-3

39. Stieb DM, Chen L, Eshoul M, Judek S. Ambient air pollution, birth weight and preterm birth: a systematic review and meta-analysis. Environ Res. 2012;117:100-111. doi:10.1016/j. envres.2012.05.007

40. Chen G, Guo Y, Abramson MJ, Williams G, Li S. Exposure to low concentrations of air pollutants and adverse birth outcomes in Brisbane, Australia, 2003-2013. Sci Total Environ. 2018;622-623:721-726. doi:10.1016/j.scitotenv.2017.12.050

41. Enders C, Pearson D, Harley K, Ebisu K. Exposure to coarse particulate matter during gestation and term low birthweight in California: variation in exposure and risk across region and socioeconomic subgroup. Sci Total Environ. 2019;653:1435-1444. doi:10.1016/j.scitotenv.2018.10.323

42. Fleischer NL, Merialdi M, van Donkelaar A, et al. Outdoor air pollution, preterm birth, and low birth weight: analysis of the world health organization global survey on maternal and perinatal health. Environ Health Perspect. 2014;122(4):425-430. doi:10.1289/ehp.1306837

43. Li Z, Yuan X, Fu J, et al. Association of ambient air pollutants and birth weight in Ningbo, 2015-2017. Environ Pollut 2019;249:629-637. doi:10.1016/j.envpol.2019.03.076

44. Pedersen M, Giorgis-Allemand L, Bernard C, et al. Ambient air pollution and low birthweight: a European cohort study (ESCAPE). Lancet Respir Med. 2013;1(9):695-704. doi:10.10 16/S2213-2600(13)70192-9

45. Xiong L, Xu Z, Tan J, et al. Acute effects of air pollutants on adverse birth outcomes in Changsha, China: a population data with time-series analysis from 2015 to 2017. Medicine (Baltimore). 2019;98(3):e14127. doi:10.1097/MD.0000000000014127

46. Hannam K, McNamee R, Baker P, Sibley C, Agius R. Air pollution exposure and adverse pregnancy outcomes in a large UK birth cohort: use of a novel spatio-temporal modelling technique. Scand $J$ Work Environ Health. 2014;518-530. doi:10.5271/sjweh.3423

47. Le HQ, Batterman SA, Wirth JJ, et al. Air pollutant exposure and preterm and term small-for-gestational-age births in Detroit, Michigan: long-term trends and associations. Environ Int. 2012;44:7-17. doi:10.1016/j.envint.2012.01.003

48. Dastoorpoor M, Idani E, Goudarzi G, Khanjani N. Acute effects of air pollution on spontaneous abortion, premature delivery, and stillbirth in Ahvaz, Iran: a time-series study. Environ Sci Pollut Res Int. 2018;25(6):5447-5458. doi:10.1007/s11356-017-0692-9

49. Dominici F, McDermott A, Zeger SL, Samet JM. On the use of generalized additive models in time-series studies of air pollution and health. Am J Epidemiol. 2002;156(3):193-203. doi:10.1093/ aje/kwf062

50. Guisan A, Thuiller W. Predicting species distribution: offering more than simple habitat models. Ecol Lett. 2005;8(9):993-1009. doi:10.1111/ele.2005.8.issue-9
51. Wood S. Mgcv: Mixed GAM Computation Vehicle with GCV/AIC/ REML Smoothness Estimation. 2012.

52. Wood SN. Generalized Additive Models: An Introduction with R. Chapman and Hall/CRC; 2017.

53. Bonzini M, Carugno M, Grillo P, Mensi C, Bertazzi PA, Pesatori AC. Impact of ambient air pollution on birth outcomes: systematic review of the current evidences. Med Lav. 2010;101 (5):341-363.

54. Ritz B, Wilhelm M, Hoggatt KJ, Ghosh JK. Ambient air pollution and preterm birth in the environment and pregnancy outcomes study at the University of California, Los Angeles. Am J Epidemiol. 2007;166(9):1045-1052. doi:10.1093/aje/kwm181

55. Peters A, von Klot S, Heier M, et al. Exposure to traffic and the onset of myocardial infarction. $N$ Engl J Med. 2004;351 (17):1721-1730. doi:10.1056/NEJMoa040203

56. Giovannini N, Schwartz L, Cipriani S, et al. Particulate matter (PM10) exposure, birth and fetal-placental weight and umbilical arterial $\mathrm{pH}$ : results from a prospective study. J Matern Fetal Neonatal Med. 2018;31(5):651-655. doi:10.1080/14767058.2017.1293032

57. Pereira G, Bell ML, Lee HJ, Koutrakis P, Belanger K. Sources of fine particulate matter and risk of preterm birth in Connecticut, 2000-2006: a longitudinal study. Environ Health Perspect. 2014;122(10):1117-1122. doi:10.1289/ehp.1307741

58. Olkhanud PB, Odsuren M, Gansukh S, et al. Association between ambient air pollution and birth weight among term infants in Ulaanbaatar, Mongolia. Pediatrics. 2018;141(1MeetingAbstract):484.

59. Salam MT, Millstein J, Li YF, Lurmann FW, Margolis HG, Gilliland FD. Birth outcomes and prenatal exposure to ozone, carbon monoxide, and particulate matter: results from the Children's Health Study. Environ Health Perspect. 2005;113 (11):1638-1644. doi:10.1289/ehp.8111

60. Topinka J, Binková B, Mračková G, et al. Influence of GSTM1 and NAT2 genotypes on placental DNA adducts in an environmentally exposed population. Environ Mol Mutagen. 1997;30 (2):184-195. doi:10.1002/(ISSN)1098-2280

61. Benevenuto SGDM, Villegas CM, Martins LC, Braga ALF, Veras MM, Pereira LAA, editors. Maternal exposure to air pollution and low birth weight: an association between environmental data and gestational outcomes. ISEE Conference Abstracts; 2015; São Paulo, Brazil.

62. Jacobs M, Zhang G, Chen S, et al. The association between ambient air pollution and selected adverse pregnancy outcomes in China: a systematic review. Sci Total Environ. 2017;579:1179-1192. doi:10.1016/j.scitotenv.2016.11.100

63. Liu Y, Xu J, Chen D, Sun P, Ma X. The association between air pollution and preterm birth and low birth weight in Guangdong, China. BMC Public Health. 2019;19(1):3. doi:10.1186/s12889018-6307-7

64. Wu $\mathrm{H}$, Jiang $\mathrm{B}$, Zhu $\mathrm{P}$, et al. Associations between maternal weekly air pollutant exposures and low birth weight: a distributed lag non-linear model. Environ Res Lett. 2018;13 (2):024023. doi:10.1088/1748-9326/aaa346

65. Sagiv SK, Mendola P, Loomis D, et al. A time-series analysis of air pollution and preterm birth in Pennsylvania, 1997-2001. Environ Health Perspect. 2005;113(5):602-606. doi:10.1289/ehp.7646

66. Bobak M, Leon DA. Pregnancy outcomes and outdoor air pollution: an ecological study in districts of the Czech Republic 1986-8. Occup Environ Med. 1999;56(8):539-543. doi:10.1136/ oem.56.8.539

67. Arroyo V, Díaz J, Salvador P, Linares C. Impact of air pollution on low birth weight in Spain: an approach to a National Level Study. Environ Res. 2019;171:69-79. doi:10.1016/j.envres.2019.01.030

68. Dedele A, Grazuleviciene R, Miskinyte A. Individual exposure to nitrogen dioxide and adverse pregnancy outcomes in Kaunas study. Int $J$ Environ Health Res. 2017;27(3):230-240. doi:10.1080/09603123.2017.1332348 
69. Ye X, Peng L, Kan H, et al. Acute effects of particulate air pollution on the incidence of coronary heart disease in Shanghai, China. PLoS One. 2016;11(3):e0151119. doi:10.1371/ journal.pone.0151119

70. Lee P-C, Roberts JM, Catov JM, Talbott EO, Ritz B. First trimester exposure to ambient air pollution, pregnancy complications and adverse birth outcomes in Allegheny County, PA. Matern Child Health J. 2013;17(3):545-555. doi:10.1007/s10995-012-1028-5

71. Liang Z, Yang Y, Qian Z, et al. Ambient PM2. 5 and birth outcomes: estimating the association and attributable risk using a birth cohort study in nine Chinese cities. Environ Int. 2019;126:329-335. doi:10.1016/j.envint.2019.02.017

72. Sheridan $\mathrm{P}$, Ilango S, Bruckner TA, Wang Q, Basu R, Benmarhnia T. Ambient fine particulate matter and preterm Birth in California: identification of critical exposure windows. Am J Epidemiol. 2019;188:1608-1615. doi:10.1093/aje/kwz120

73. Han Y, Ji Y, Kang S, et al. Effects of particulate matter exposure during pregnancy on birth weight: a retrospective cohort study in Suzhou, China. Sci Total Environ. 2018;615:369-374. doi:10.1016/j.scitotenv.2017.09.236

74. Schwartz J. Harvesting and long term exposure effects in the relation between air pollution and mortality. Am J Epidemiol. 2000;151(5):440-448. doi:10.1093/oxfordjournals.aje.a010228

75. Stieb DM, Chen L, Hystad P, et al. A national study of the association between traffic-related air pollution and adverse pregnancy outcomes in Canada, 1999-2008. Environ Res. 2016;148:513-526. doi:10.1016/j.envres.2016.04.025

76. Jiang LL, Zhang YH, Song GX, et al. A time series analysis of outdoor air pollution and preterm birth in Shanghai, China. Biomed Environ Sci. 2007;20(5):426-431.

77. Zhao Q, Liang Z, Tao S, Zhu J, Du Y. Effects of air pollution on neonatal prematurity in Guangzhou of China: a time-series study. Environ Health. 2011;10:2. doi:10.1186/1476-069X-10-2

78. Huang C, Nichols C, Liu Y, et al. Ambient air pollution and adverse birth outcomes: a natural experiment study. Popul Health Metr. 2015;13(1):17. doi:10.1186/s12963-015-0050-4

79. Johnson S, Bobb JF, Ito K, et al. Ambient fine particulate matter, nitrogen dioxide, and preterm birth in New York City. Environ Health Perspect. 2016;124(8):1283-1290. doi:10.1289/ehp.1510266

80. Qian Z, Liang S, Yang S, et al. Ambient air pollution and preterm birth: a prospective birth cohort study in Wuhan, China. Int J Hyg Environ Health. 2016;219(2):195-203. doi:10.1016/j.ijheh.2015.11.003

81. Tabacova S, Nikiforov B, Balabaeva L. Postnatal effects of maternal exposure to nitrogen dioxide. Neurobehav Toxicol Teratol. 1985;7(6):785-789.

82. Sagai M, Ichinose T. Biochemical effects of combined gases of nitrogen dioxide and ozone. IV. Changes of lipid peroxidation and antioxidative protective systems in rat lungs upon life span exposure. Toxicology. 1991;66(2):121-132. doi:10.1016/0300-483X(91)90213-K

83. Wilhelm M, Ritz B. Local variations in CO and particulate air pollution and adverse birth outcomes in Los Angeles County, California, USA. Environ Health Perspect. 2005;113 (9):1212-1221. doi:10.1289/ehp.7751

84. Li S, Guo Y, Williams G. Acute impact of hourly ambient air pollution on preterm birth. Environ Health Perspect. 2016;124 (10):1623-1629. doi:10.1289/EHP200

85. Guan T, Xue T, Gao S, et al. Acute and chronic effects of ambient fine particulate matter on preterm births in Beijing, China: a time-series model. Sci Total Environ. 2019;650(Pt 2):1671-1677. doi:10.1016/j.scitotenv.2018.09.279

86. Hackmann D, Sjöberg E. Ambient air pollution and pregnancy outcomes - a study of functional form and policy implications. Air Qual Atmos Health. 2017;10(2):129-137. doi:10.1007/ s11869-016-0415-2
87. Liu C, Sun J, Liu Y, et al. Different exposure levels of fine particulate matter and preterm birth: a meta-analysis based on cohort studies. Environ Sci Pollut Res Int. 2017;24 (22):17976-17984. doi:10.1007/s11356-017-9363-0

88. Sun X, Luo X, Zhao C, et al. The associations between birth weight and exposure to fine particulate matter (PM2.5) and its chemical constituents during pregnancy: a meta-analysis. Environ Pollut. 2016;211:38-47. doi:10.1016/j.envpol.2015.12.022

89. Rappazzo KM, Daniels JL, Messer LC, Poole C, Lobdell DT. Exposure to fine particulate matter during pregnancy and risk of preterm birth among women in New Jersey, Ohio, and Pennsylvania, 2000-2005. Environ Health Perspect. 2014;122 (9):992-997. doi:10.1289/ehp.1307456

90. Li X, Huang S, Jiao A, et al. Association between ambient fine particulate matter and preterm birth or term low birth weight: an updated systematic review and meta-analysis. Environ Pollut. 2017;227:596-605. doi:10.1016/j.envpol.2017.03.055

91. Lee PC, Talbott EO, Roberts JM, Catov JM, Sharma RK, Ritz B. Particulate air pollution exposure and C-reactive protein during early pregnancy. Epidemiology. 2011;22(4):524-531. doi:10.1097/EDE.0b013e31821c6c58

92. van den Hooven EH, de Kluizenaar Y, Pierik FH, et al. Chronic air pollution exposure during pregnancy and maternal and fetal C-reactive protein levels: the Generation R Study. Environ Health Perspect. 2012;120(5):746-751. doi:10.1289/ehp.1104345

93. Schifano P, Lallo A, Asta F, De Sario M, Davoli M, Michelozzi P. Effect of ambient temperature and air pollutants on the risk of preterm birth, Rome 2001-2010. Environ Int. 2013;61:77-87. doi:10.1016/j.envint.2013.09.005

94. Wang Q, Benmarhnia T, Li C, et al. Seasonal analyses of the association between prenatal ambient air pollution exposure and birth weight for gestational age in Guangzhou, China. Sci Total Environ. 2019;649:526-534. doi:10.1016/j.scitotenv.2018.08.303

95. Klepac P, Locatelli I, Korošec S, Künzli N, Kukec A. Ambient air pollution and pregnancy outcomes: a comprehensive review and identification of environmental public health challenges. Environ Res. 2018;167:144-159. doi:10.1016/j.envres.2018.07.008

96. Lavigne E, Yasseen AS III, Stieb DM, et al. Ambient air pollution and adverse birth outcomes: differences by maternal comorbidities. Environ Res. 2016;148:457-466. doi:10.1016/j. envres.2016.04.026

97. Liu S, Krewski D, Shi Y, Chen Y, Burnett RT. Association between gaseous ambient air pollutants and adverse pregnancy outcomes in Vancouver, Canada. Environ Health Perspect. 2003;111(14):1773-1778. doi:10.1289/ehp.6251

98. Storvik M, Huuskonen P, Pehkonen P, Pasanen M. The unique characteristics of the placental transcriptome and the hormonal metabolism enzymes in placenta. Reprod Toxicol. 2014;47:9-14. doi:10.1016/j.reprotox.2014.04.010

99. Bobak M. Outdoor air pollution, low birth weight, and prematurity. Environ Health Perspect. 2000;108(2):173-176. doi:10.1289/ehp.00108173

100. Pereira LA, Loomis D, Conceicao GM, et al. Association between air pollution and intrauterine mortality in São Paulo, Brazil. Environ Health Perspect. 1998;106(6):325-329. doi:10.1289/ ehp.98106325

101. Kannan S, Misra DP, Dvonch JT, Krishnakumar A. Exposures to airborne particulate matter and adverse perinatal outcomes: a biologically plausible mechanistic framework for exploring potential effect modification by nutrition. Environ Health Perspect. 2006;114(11):1636-1642. doi:10.1289/ehp.9081 


\section{Publish your work in this journal}

The International Journal of Women's Health is an international, peerreviewed open-access journal publishing original research, reports, editorials, reviews and commentaries on all aspects of women's healthcare including gynecology, obstetrics, and breast cancer. The

manuscript management system is completely online and includes a very quick and fair peer-review system, which is all easy to use. Visit http://www.dovepress.com/testimonials.php to read real quotes from published authors.

Submit your manuscript here: https://www.dovepress.com/international-journal-of-womens-health-journal 